\title{
Enhanced photodynamic leishmanicidal activity of hydrophobic zinc phthalocyanine within archaeolipids containing liposomes [Corrigendum]
}

Perez AP, Casasco A, Schilrreff P, et al. Int J Nanomedicine.

2014;9:3335-3345.

The author list on page 3335 was incorrect, it should have been:

Ana Paula Perez ${ }^{1}$

Agustina Casasco ${ }^{2}$

Priscila Schilrreff ${ }^{1}$

Maria Victoria Defain Tesoriero ${ }^{1,3}$

Luc Duempelmann ${ }^{1}$

Juan Sebastián Pappalardo ${ }^{4}$

Maria Julia Altube ${ }^{1}$

Leticia Higa $^{1}$

Maria Jose Morilla ${ }^{1}$

Patricia Petray ${ }^{2}$

Eder L Romero ${ }^{1}$

${ }^{1}$ Programa de Nanomedicinas, Departamento de Ciencia y Tecnología, Universidad Nacional de Quilmes, ${ }^{2}$ Servicio de Parasitología y Enfermedad de Chagas, Hospital de Niños Ricardo Gutiérrez, ${ }^{3}$ Unidad Operativa Sistemas de Liberación Controlada, Centro de Investigación y Desarrollo en Química, Instituto Nacional de Tecnología Industrial (INTI), Buenos Aires, ${ }^{4}$ Virology Institute, Center for Research in Veterinary and Agronomic Sciences, National Institute for Agricultural Technology (INTA), Hurlingham, BA, Argentina

\section{Publish your work in this journal}

The International Journal of Nanomedicine is an international, peerreviewed journal focusing on the application of nanotechnology in diagnostics, therapeutics, and drug delivery systems throughou the biomedical field. This journal is indexed on PubMed Central, MedLine, CAS, SciSearch ${ }^{\circledR}$, Current Contents ${ }^{\circledR} /$ Clinical Medicine,
Journal Citation Reports/Science Edition, EMBase, Scopus and the Elsevier Bibliographic databases. The manuscript management system is completely online and includes a very quick and fair peer-review system, which is all easy to use. Visit http://www.dovepress.com/ testimonials.php to read real quotes from published authors. 